Електронне наукове фахове видання "Ефективна економіка" включено до переліку наукових фахових видань України з питань економіки

(Категорія «Б», Наказ Міністерства освіти і науки України від 11.07.2019 № 975) www.economy.nayka.com.ua | № 7, 2021 | 29.07.2021 p.

DOI: $\underline{10.32702 / 2307-2105-2021.7 .200}$

УДК 658.3

\author{
Huang Bo, \\ Master's student of the Department of Management, \\ Sumy National Agrarian University \\ ORCID ID: 0000-0002-3276-4350 \\ V. Makarova \\ PhD in Economics, Associate Professor,
}

Associate Professor of the Department of Marketing and logistics, Sumy National Agrarian University

ORCID ID: 0000-0003-1076-9246

\title{
DIRECTIONS OF IMPROVEMENT HR - MANAGEMENT IN FINANCIAL INSTITUTIONS OF GUANXI PROVINCE OF CHINA
}

\author{
Хуан Бо, \\ магістрант кафедри менеджменту, \\ Сумський національний аграрний університет \\ B. В. Макарова, \\ к. е. н., доцент, доцент кафедри маркетингу та логістики, \\ Сумський національний аграрний університет
}

\section{НАПРЯМКИ ВДОСКОНАЛЕННЯ УПРАВЛІННЯ ПЕРСОНАЛОМ В ФІНАНСОВИХ УСТАНОВАХ ПРОВІНЦЇ̈ ГУАНСІ КИТАЮ}

As a result of the study, the authors analyzed the development and current trends in personnel management in financial institutions in Guangxi Province, China. The article emphasizes that the consequences of global economic integration and cultural diversity have violated the traditional system and mechanism of labor management. Human resource management in enterprises ensures the integration of different political systems, legal norms, customs and cultural traditions of staff cohesion. It is proved that the concept and mode of personnel management need to be adjusted and changed depending on the field of activity. It is determined that such channels of attracting employees as social networks are becoming more and more popular in China. The authors propose specific measures for the development of human resources in the financial sector and methods of improvement, including salary system, employee development system, work optimization, implementation of improved performance management system, and improvement of training and human resource management in the financial sector. Also, the factors influencing the supply of human resources in the financial sector are analyzed. These factors include media publicity, the potential to increase the capacity of financial staff, and the impact of reasonable compensation. It is substantiated that for the employees of the financial sphere the two most critical moments are the improvement of personal abilities and a good salary system.

It is determined that the development of Internet finance has a significant impact on China's traditional financial sector. In order to cope with the rapid development of Internet technologies and the changing social environment, the human resource model of the financial industry must also include positioning analysis. This analysis not only solves many problems that exist in the current human 
resource management, but also, its implementation can provide a constant update of human resource management and, ultimately, realize the supporting role of human resource management in the development of financial enterprises.

В результаті проведеного дослідження авторами проаналізовано розвиток та сучасні тендениії управління персоналом в фінансових установах провіниії Гуансі Китаю. В статті наголошується на тому, щзо через наслідки глобальної економічної інтеграції та культурне різноманіття порушено традиційну систему та механізм управління трудовими ресурсами. Управління трудовими ресурсами на підприємствах забезпечує інтеграцію різних політичних систем, правових норм, звичаїв та культурних традицій згуртованості персоналу. Доведено, щуо конщепцію та режим управління персоналом потрібно коригувати та змінювати $в$ залежності від сфери діяльності. Визначено, щь все більшої популярності в Китаї набувають такі канали залучення прачівників як соціальні мережі. Авторами запропоновані конкретні заходи щзодо розвитку людських ресурсів у фінансовій галузі та методи вдосконалення, включаючи систему заробітної плати, систему розвитку співробітників, оптимізацію роботи, впровадження вдосконаленої системи управління ефективністю, вдосконалення системи підготовки та вдосконалення управління людськими ресурсами у фінансовій галузі. Також, проаналізовано фактори, щзо впливають на пропозицію людських ресурсів у фінансовій галузі. Ці фактори включають публічність засобів масової інформачії, потенціал підвищення здатності фінансового персоналу та вплив розумної компенсації. Обтрунтовано, щуо для працівників фінансової сфери двома найбільш критичними моментами $\epsilon$ вдосконалення особистих здібностей та хороша система заробітної плати.

Визначено, щуо розвиток Інтернет-фінансів має значний вплив на традиційну фінансову галузь Китаю. Для того, щьоб впоратися з бурхливим розвитком Інтернет-технологій та мінливим соиіальним середовищем, модель управління людськими ресурсами фінансової індустрї також повинна включати аналіз позиціонування. Даний аналіз не тільки вирішує багато проблем, що існують у поточному управлінні людськими ресурсами, але й крім того, його здійснення може забезпечити постійне оновлення управління людськими ресурсами та, зрештою, усвідомити допоміжну роль управління людськими ресурсами у розвитку фінансових підприємств.

Key words: human resources; HR-management; Fintech; financial institutions; Guanxi Province.

Ключові слова: трудові ресурси; управління персоналом; фінансова галузь; фінансові установи; провінція Гуансі.

Problem statement. The development of Fintech has a massive impact on the traditional financial industry. In order to cope with the rapid development of Internet technology and the changing social environment, the human resource management model of the financial industry also needs to carry out positioning analysis, which not only solves many problems existing in the current human resource management, Moreover, it can ensure the continuous updating of human resource management, and ultimately realize the supporting role of human resource management in the development of financial enterprises. On the other hand, financial technology has changed the service mode of the traditional financial industry and correspondingly changed the human resource management structure of financial enterprises. The innovation of human resource management mode and the change of management concept in the Internet environment has also become a new topic of human resource management research in the new era. Human resource is an essential resource of financial enterprises.

Analysis of recent research and publications. Many scholars have noticed the important role of HRmanagement: Xie Lei [1], Chen Wenlan [2], Cui Maojun [3], Wang Yuxue [4], Hasan I., Wachtel P., Zhou M. [5] and many others. Evaluating scientific works on the researched problem, it is worth noting the lack of a holistic substantiation of the theoretical and methodological foundations of the concept of HR-management in financial institutions.

Research objective. The purpose of the article is a theoretical study of the nature, significance and features of HR-management in financial institutions and finding the ways of its improving.

Research results. Research on the effectiveness evaluation method of human resource management in financial institutions is the key to improve the level of human resource management in financial institutions. The various modules of human resource management include salary system, employee development system, performance system, talent cultivation, talent management, and human resource work orientation. Financial institutions analyze these six aspects in order to 
improve human resource management methods by financial institutions. Based on the financial institutions in Guangxi area as the research object, the financial institutions of human resource management in Guangxi area were analyzed, and the Guangxi regional financial professionals think, salary system and career development channel is far more important than other aspects of attention degree and the performance management system and cultivation of talents, the high-level construction is ignored by many financial institutions. Project needs regarding employee motivation and development systems are indeed the most common. The direction of the reform is mainly to change from the relatively administrative system in the past to a more market-oriented model and to provide employees with a clearer development path and a broader development space. However, incentives and constraints are inseparable, and development and cultivation are also closely linked.

With the development of the financial industry in Guangxi, there is an urgent need for many Fintech talents to support the steady development of Guangxi's economy. The number of financial practitioners in Guangxi has increased year by year. The number of financial practitioners in Guangxi has increased from 110,100 in 2011 to 196,000 in 2019. By comparing the number of financial practitioners in Guangxi in the recent ten years, the increment is noticeable. Figure 1 shows the number of financial practitioners in Guangxi Province.

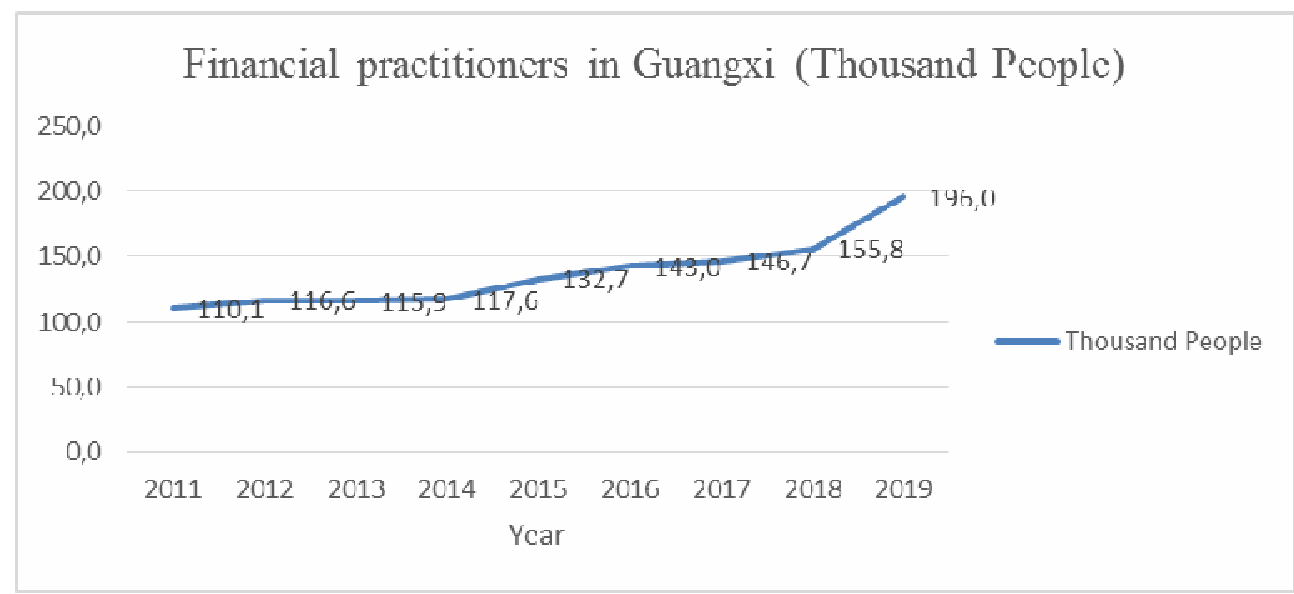

Figure 1 - Number of financial practitioners in Guangxi Data Source: China Statistical Yearbook

The total amount of talents in Guangxi is insufficient, which cannot meet the needs of economic development, especially high-level and highly educated. From the perspective of industrial talent demand, in addition to a few industries' demand for talents can be met, there is a big gap in the demand for talents in other enterprises and industries, which is difficult to be met at present.

In the financial industry, human resource development and training should be optimized in the following aspects:

\section{(1) Salary system}

Salary system improvement direction: Salary system optimization must rely on an objective and reasonable basis, so the reform of the salary system should start from its supporting system. The salary system is the terminal mapping of multiple mechanisms, and the supporting system behind it is the important factor to determine whether it is fair and effective. Therefore, the compensation reform often needs to start from its supporting system rather than just the salary system itself. Different support systems convey different values, and financial institutions should first clarify what values they want to convey to their employees through compensation. If we want to encourage employees to undertake more critical and complex post-work, we must reflect the orientation of post value; If we want to encourage employees to pursue a higher level of performance, we should reflect the orientation of performance value. Often, it may be necessary to convey a comprehensive set of values, so there will be a need for progressive design in the salary system. Figure 2 shows the basis of employee compensation differentiation. 


\section{The basis of employee compensation differ entiation}

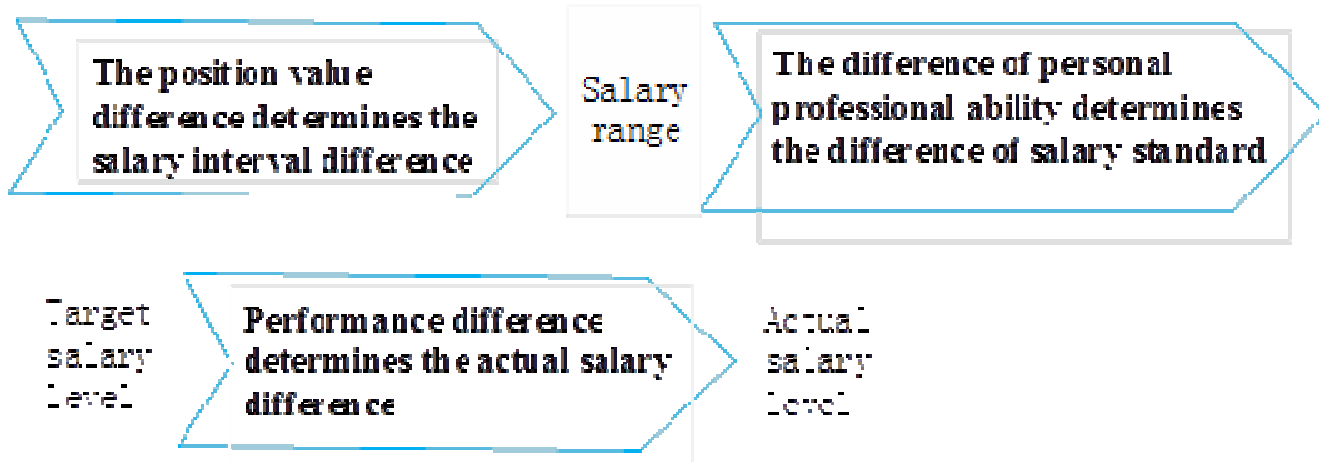

Figure 2 - The basis of employee compensation differentiation Source: systematized by the author

(2) Staff career development system

Staff career development system: Staff career development system for the construction of the sequence must be taken into account comprehensively, level standard, and evaluation mechanism of the perfect career development system is that the Banks provide opportunities to the employees and channel, through the establishment of the system, staff can see the expectations of individual enterprises, and individual in different periods in the enterprise can achieve the goal and the possibility. This system is usually the basis for the construction of the bank's rank system. Furthermore, banks can put forward more reasonable qualifications and ability requirements for different levels of personnel, and on this basis, they can develop differentiated compensation standards for different levels of personnel. Therefore, a perfect employee career development system should classify employees and make them adjust up and down predictably in the appropriate category and level system (fig. 3).

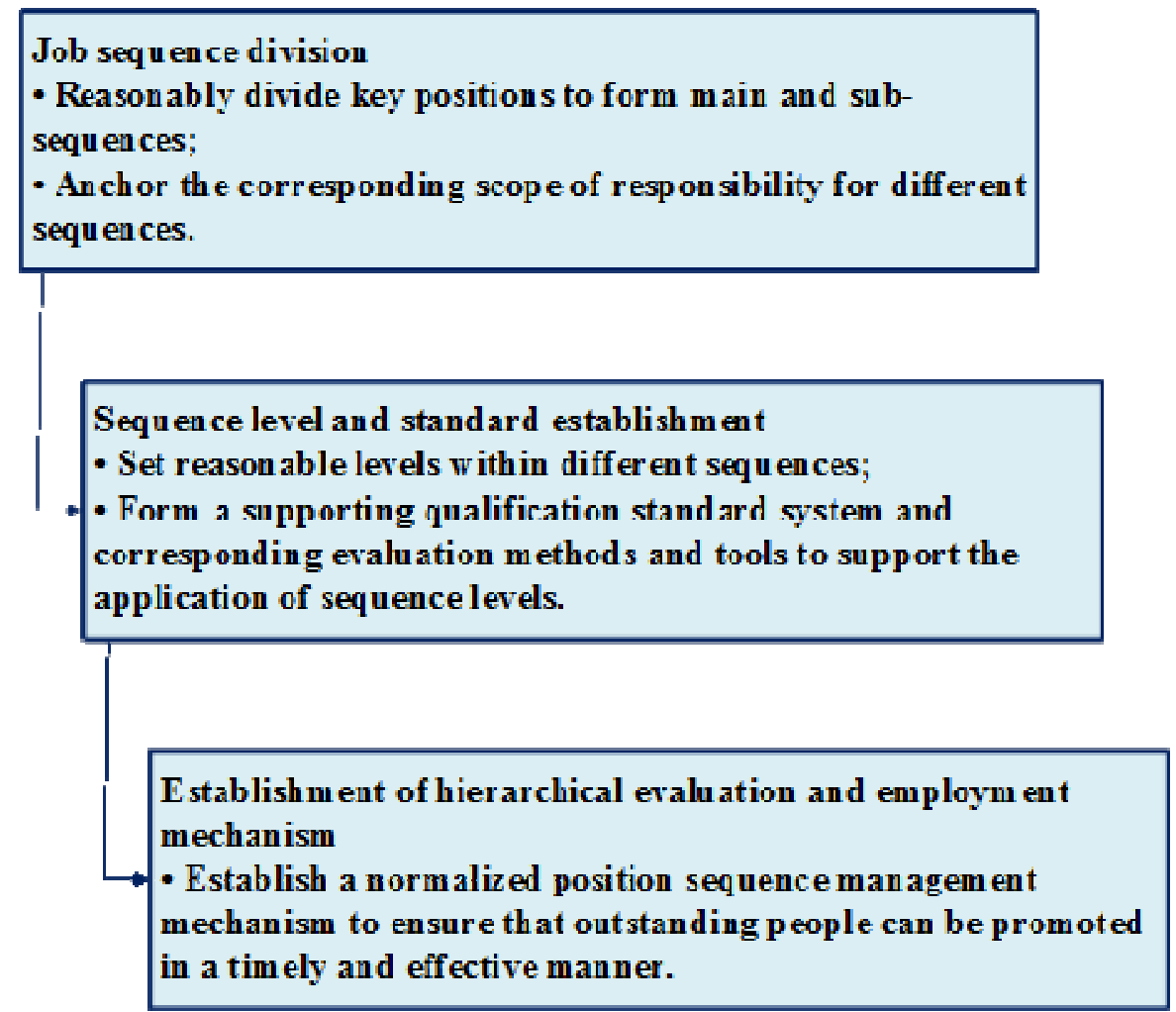

Figure 3 - The employee career development system Source: systematized by the author

(3) Performance optimization

Financial institutions should improve the assessment contents and standards at all levels to avoid pressure transmission faults and promote their effective implementation with the help of the system to solve the problem of 
performance pressure transmission. It is necessary to improve the assessment system at all levels from top to bottom, especially for groups with current assessment faults.

However, this is not the simple grading or 360-degree qualitative assessment that many financial institutions are implementing. This simple qualitative evaluation of a certain extent, to distinguish between the employee's performance, but it has a fatal weakness, namely the heavy form light content, the lack of explicit assessment contents and standards, and that is what financial institutions conduct strategy into performance pressure and clear to the essential carrier of various levels, are also at the heart of the implementation of the evaluation. Therefore, the improvement of assessment content and standards is an important step to solve the transmission fault of performance pressure, which may require the help of various professional methodologies and tools, such as the balanced scorecard. Figure 4 shows the assessment contents and standards.

(4) Introduce performance management system at the same time

The performance management system is a platform to present the assessment contents and standards to employees, making performance management work more efficient and reliable. Meanwhile, it can also precipitate and accumulate the performance data of the whole bank as solid support for strategic and business analysis and provide assistance for leaders' decision-making. Many mature performance management system suppliers are in the market, and consulting companies can also provide customized system development services. However, banks must make clear their own needs to choose the most appropriate products and services.

(5) Improve the training system

When financial institutions establish a hierarchical and classified talent standard system, it becomes more natural to build a hierarchical and classified curriculum system based on it. Only such a curriculum system can genuinely meet the talent development needs of financial institutions and maximize the input-output ratio of resources invested in the training system.

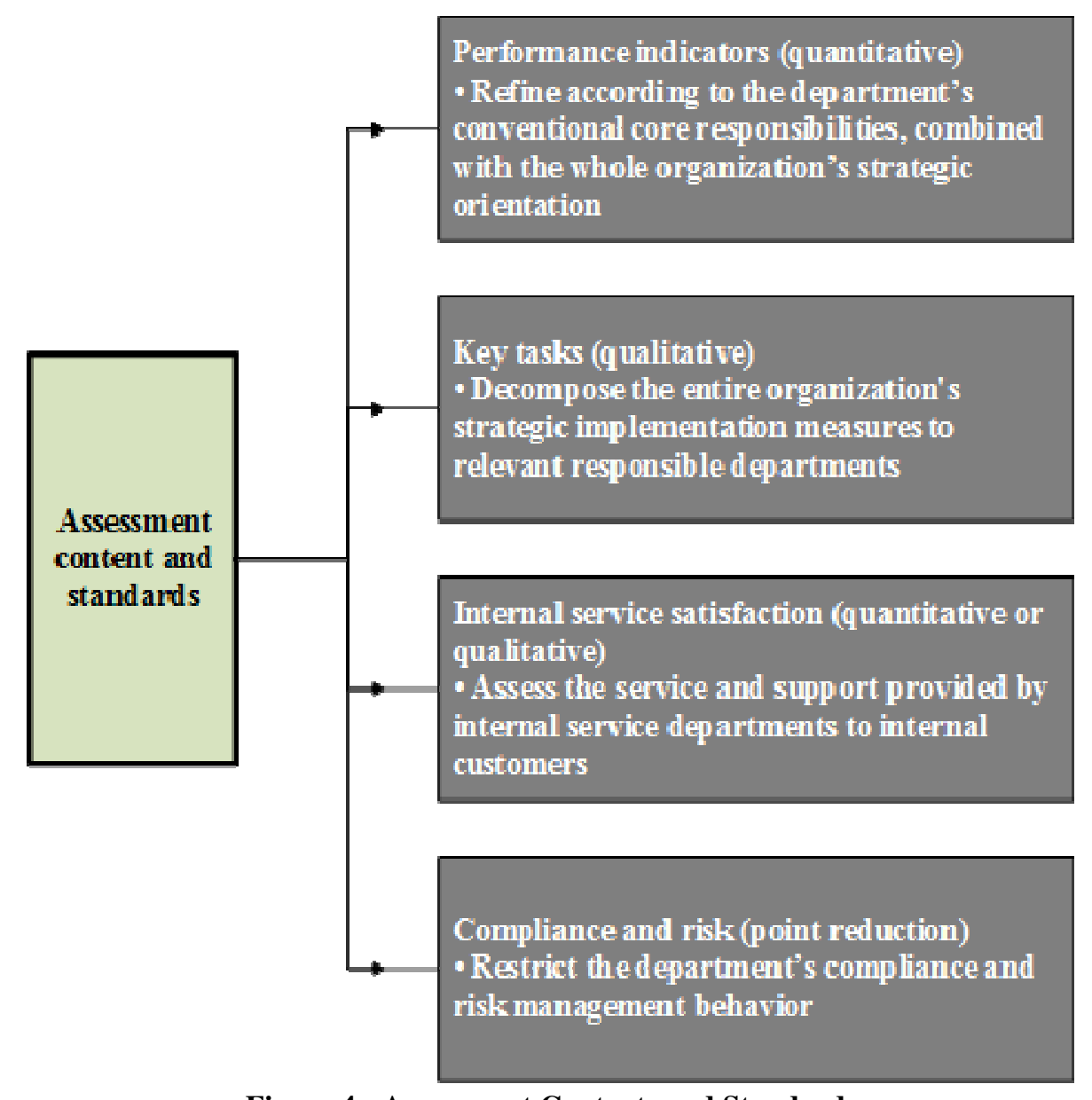

Figure 4 - Assessment Contents and Standards Source: systematized by the author

It is found that financial industry enterprises have realized the importance of establishing a talent reserve internship program, most enterprises have carried out the corresponding internship program, and some enterprises even directly take the internship program as one of the leading recruitment methods to select graduates. Thus, most enterprises in the financial industry have the strategic thought of reserve talents. The critical issue of the research is how to attract more high-quality talents to actively participate in the internship programs provided by the enterprises through research. Combined with the enterprise's operation situation and market situation, the design of a talent reserve management strategy 
is in line with the enterprise's requirements and can attract more high-quality talents to provide more opportunities for both enterprises and individuals.

The key influencing factors of talent demand strategy design in human resource management are concentrated in three aspects: media publicity, ability improvement, and reasonable salary.

\section{Media publicity}

As one of the factors affecting talent reserve projects in the financial industry, the absolute value of the influence coefficient of media publicity is the largest among the three factors. Therefore, media publicity is the most important factor affecting whether college graduates choose to apply for internship programs. The purpose of the internship program for talent reserve in the financial industry is to help enterprises provide a process that can help enterprises and potential candidates understand and contact before recruiting college graduates. Enterprises need to attract many high-quality talents to apply for the internship program to give enterprises more choices. Therefore, enterprises can set up a selection mechanism to select more outstanding talents as human resources for talent reserve projects. Then, before college graduates have not been exposed to financial practices or work, media publicity has become a window for college graduates to understand enterprises. Enterprises to design a good internship program issued by media, detailed introduces the time and place of the internship program, task, position requirements, and pay, by publishing news that college graduates can understand the enterprise's demand, and design the content of the internship program and expectation of internship program participants so that the potential participants in the application for delivery.

The financial industry, thus, media propaganda message published to become the initial point of enterprise talent pool's internship program, in today's Internet is developing rapidly, the use of the information transmission medium is very convenient, information transmission cost is also meager, how to efficient use of information transmission media, introduction of effective transfer the internship project information is especially critical of the enterprise, can widely be passed already, And can be brief and precise, for enterprises, from the beginning of the internship information release has begun to compete with other enterprises began to snatch talents. Through the study, we can find that enterprise information release mainly focuses on the following four channels: university release, We Chat subscription number, enterprise official website, third-party information comprehensive website. Because the internship program of the enterprise has vital timeliness and pertinence, there is no need to use more print advertising to deliver. Many enterprises in the process of campus recruitment for many years, and the university have established a long-term cooperation strategic relationship. Therefore, the enterprise can enter the universities choose specific time held a briefing session internship programs, communicate directly with the university graduates face to face, can be the first time to solve related application problem of college graduates, They can also get direct feedback from college graduates on their internship programs. However, this way is limited to intra-city communication, which is not conducive to obtaining excellent students from neighboring colleges and universities. So companies will be set up on the official website to recruit high-quality talents to participate in the internship program so that college graduates while browsing the website of the project information, can also understand the culture of enterprises from the perspective of the main business and critical project business information can help the college graduates fully understand the official propaganda of enterprise information. However, this approach is much targeted. Only college graduates who set the enterprise as their job-hunting enterprise in advance will pay much attention to the enterprise's official website information, which is not conducive to the more comprehensive transmission of the enterprise's internship program. Therefore, enterprises directly apply for official public accounts on the We Chat platform, which helps college graduates to view the latest corporate recruitment or corporate culture promotion information at any time through mobile terminals, which significantly helps enterprises overcome the limitations of mobile terminals brought by official websites. There is similar to the official website of the propaganda way; however, information audience limitation problem. Therefore, the enterprise will pay information publication costs. The specialized third-party information integrated their internship program-related information posted on the website. Potential participants to participate in the internship program will provide fast and efficient project-related information. If interested in reading, further information about the enterprise can be obtained in other ways. These media are intended to help college graduates learn the internship program information of enterprises more quickly and conveniently. By comprehensively utilizing their advantages, they can help potential participants better understand the operation status of enterprises before application. Enterprises also pass project information and current development situation, and future development trend information to college graduates through these ways so that enterprises can harvest more potential talents with relevant needs.

\section{The potential of improving the ability of financial personnel}

Financial industry enterprises to carry out the talent pool internship project aims to discover, and excavation conforms to the enterprise future development strategy of high-quality talent, the internship program is the enterprise to the current operating platform for university graduates in entering the society, the financial industry, contact the work ahead of time the opportunity, is also found that the chance of talent of the reserves and mining enterprises. Based on this, the design and work tasks of the internship program need to develop and stimulate the potential of the working ability and comprehensive ability of the participants. Participants must adapt to the enterprise daily operation work environment, also in order to complete the project tasks to overcome many difficulties, many technical, cultural, spiritual. For participants, which is an enterprise for its provides practical training platform and opportunity, participants complete the internship program. Even in the two-way choice decisions of the enterprise, without a good rapport, the experience is a rare opportunity for the participants to develop their abilities. In order to achieve this goal, the project design of financial enterprises must be practical and challenging to a certain extent. It is a new exploration for the business expansion of enterprises and an opportunity for participants to broaden their horizons and improve their abilities. For different enterprises' operation, future development strategies and talent needs, the business positions provided by internship 
programs will be different. Enterprises carrying out a challenging talent reserve internship program need to provide participants with a self-breakthrough practice platform as far as possible under the premise of protecting trade secrets. If the significance of the challenge is not reached, the potential participants cannot improve the attraction, and high-quality talents cannot achieve the original intention of participation in the internship program, they will not gather to apply for participation in the project. Therefore, an internship program has the significance of enhancing participants' ability and can help enterprises gather more excellent and high-quality potential talents.

\section{The influence of reasonable salary}

The human resource cost of financial industry enterprises accounts for more than half of the operating cost of enterprises. The human resource cost mainly includes the employee compensation and welfare system. As an essential part of human resources, the talent reserve internship program also needs to develop a reasonable salary system. Although the participants of the internship program are college graduates who have not entered the society, the salary design of the internship program can reflect the recognition degree of the enterprise carrying out the internship program and the importance of human resources, which is the feedback of the enterprise to the internship program that the participants can intuitively understand. Especially in the financial industry, the turnover of talents is widespread. The two primary reasons for the turnover are matching job contribution and salary and the sufficient development space offered by the current working platform. The importance of establishing a sound salary system is self-evident. Although the internship program provides full participation and ability improvement to the participants in all aspects, the overall effect of the internship program will be significantly affected if the salary design fails to make the participants feel satisfied with the tasks completed during the project. Reasonable salary design is not only the equivalent return of labor for work tasks, nor does it remain unchanged, but organically combines the work content and career development planning of the participants with the enterprise's strategic development to realize the design of a strategic and incentive salary system. According to the enterprise to provide internship program task, horizontally compared with other at competitive enterprise, project tasks and float level, give attention to two or more things take the salary design for customization, external to be competitive, able to attract more excellent talents into the company in, internally to have fairness, to retain more good on-the-job employees. Flexible and incentive compensation design can help enterprises retain more high-quality project participants discovered and discovered.

From the perspective of human resource management in the financial industry, it can be found that the improvement of personal ability and a sound salary system are the two most critical factors for talents, and they also have the most sincere work needs for the enterprises they work for, regardless of internship programs.

Strategy is the action guide and development goal that a forward-looking and instructive enterprise must realize in a certain period. The talent reserve demand management planning should be rooted in the talent demand and formulate the corresponding content. The talent reserve demand management strategy is a project in human resource management. Enterprises in a comprehensive grasp of the current operating situation and future development orientation under the premise of enterprise to clear their position in the industry and has the resources to the enterprise unique resources and platform to attract talent as the essential features, according to the actual operating conditions of enterprises, planning the real demand of talent type, set up related jobs, formulation of work tasks, It can not only reduce the blindness of talent recruitment but also effectively develop a talent reserve resource planning that is closely combined with the enterprise development strategy and can play a supporting role. Only after the enterprise has defined its own needs, combined with the characteristics of the post, can it provide the corresponding job demands and future career planning of the post to attract the corresponding talents in a targeted way. Suppose companies cannot give a precise design purpose and future development prospects, potential talent when applying for the job, not clear their future career development and career planning. In that case, the enterprise provides the platform for talents and resources, there is no appeal and gathered the less talent, enterprises can choose the scope and ways of constrained, Fail to form a virtuous circle of talent reserve management system, will cause significant losses to enterprises, is not conducive to the future development of enterprises.

The design of a compensation system is another critical interactive process between enterprises and talents. Talents create value for enterprises and get remuneration recognized for their work content and achievements. Enterprises hire talents to complete specific tasks and pay the corresponding remuneration. The design of a salary system has always been the key and challenging problem in human resource management, especially in the financial industry. One of the main reasons for frequent staff turnover is that employees are dissatisfied with the current labor remuneration. Compensation system design is the critical problem in constructing a fair and competitive, fairness is how to measure or balance between enterprise internal employee compensation, competitive is with the types of jobs and competition within the industry the company pay more attractive when compared to. Therefore, a scientific and reasonable compensation system is the goal of enterprises to build a compensation system. At present, to stimulate employees' enthusiasm for work and ensure the fairness of salary, enterprises distribute salaries according to proportion, including basic salary for specific positions, post salary for specific tasks, seniority salary for working years, and performance-based salary for salary measuring work performance. In the part of the wages, includes both the objective conditions of post setting, remuneration and reward employees loyalty reward, and dig potential of employees work reward, from different angles to consider the requirements and practical and scientific compensation design fully, let employees to their jobs, work content and work with clear feedback. The competitiveness of the compensation system is closely related to the nature of the positions and the operation of the enterprise, which requires the human resources department to comprehensively evaluate the current operation of the enterprise and the nature of the position setting, and the enterprise should not be burdened with high human resources operation costs in the pursuit of competitive remuneration. 
Therefore, the compensation system's design reflects the enterprise's sincerity in recruiting talents and a recognition of the talents' value and direct feedback of their work content and working ability. Therefore, it is a significant influencing factor for both enterprises and individuals.

Incentive theory Maslow's hierarchy of needs Maslow (fig.5) put forward the hierarchy of human needs in his theory of human motivation published in 1943. It is believed that human beings mainly include the following five needs: first, physiological needs. Including hunger, thirst, clothing, shelter, sex and other needs, is the most basic requirement of human survival. Second, security needs. This is the need for human beings to protect their safety, get rid of the threat of career and property loss, avoid the invasion of occupational diseases, and come into contact with harsh supervision. Third, emotional needs. The need of this level includes two aspects: the need for fraternity, that is, everyone needs a harmonious relationship or friendship and loyalty between partners and colleagues; care Fourth, the need for respect.

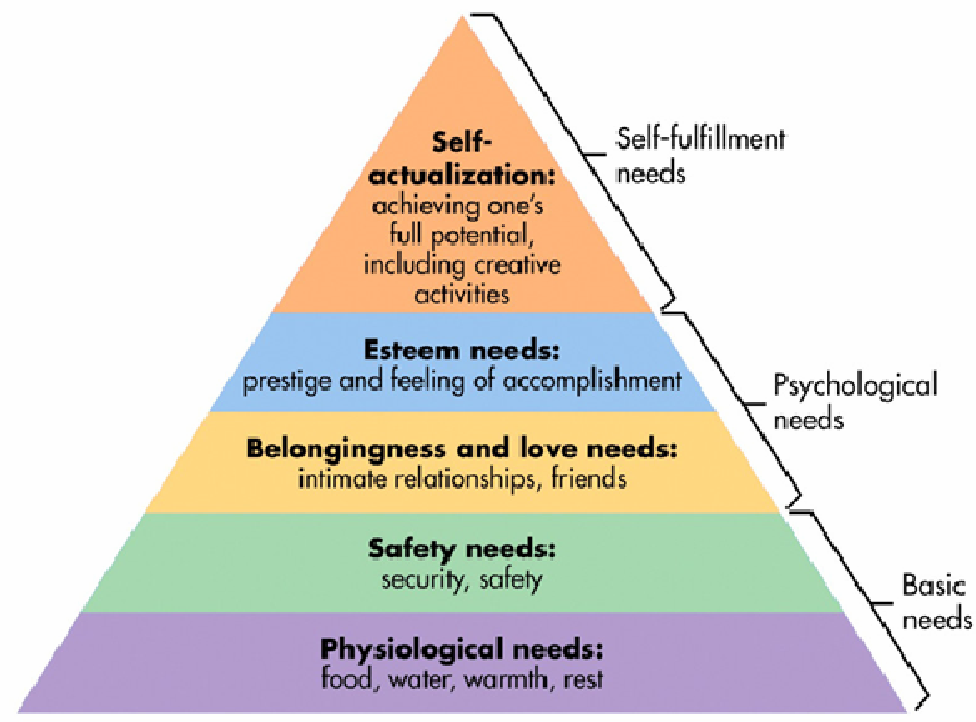

Figure 5 - Maslow's hierarchy of needs

Everyone wants to have a stable social status and requires that the individual's ability and achievements be recognized by society. The fifth is the need for self-realization. This is the need of the highest level. It refers to the need to realize one's ideal and ambition, to give full play to one's ability to the greatest extent, and to accomplish everything commensurate with one's ability. Self-realization is trying to realize one's potential and make oneself more and more the character one expects.

People have these five kinds of needs at different levels, but the urgency of these needs is different in different periods. The most urgent need of people is the main reason and motivation to motivate people to act. People's needs are gradually transformed from external satisfaction to internal satisfaction.

Herzberg's two-factor theory, also known as incentive health care theory, is proposed by Fredrick Herzberg, an American psychologist. In a 1959 job satisfaction survey, Herzberg found that people's job satisfaction is an important force to motivate people's work behavior, and the factors leading to satisfaction and dissatisfaction are two kinds of factors with completely different nature.

According to Herzberg, the factors (fig. 6) that can bring a positive attitude, satisfaction and motivation are called "motivation factors", which are the factors that can meet the needs of individual self-realization, including achievement, appreciation, challenging work, increased work responsibility, and opportunities for growth and development. If these factors are available, they can produce greater incentives for people. In the modern employee material incentive system, human resource is the core strength of the enterprise and the most important work incentive in the management. As an important human resource content, it is the critical factor that determines the success or failure of the enterprise. Therefore, it is of great importance to an enterprise. 


\section{Two Factor Theory of Motivation}
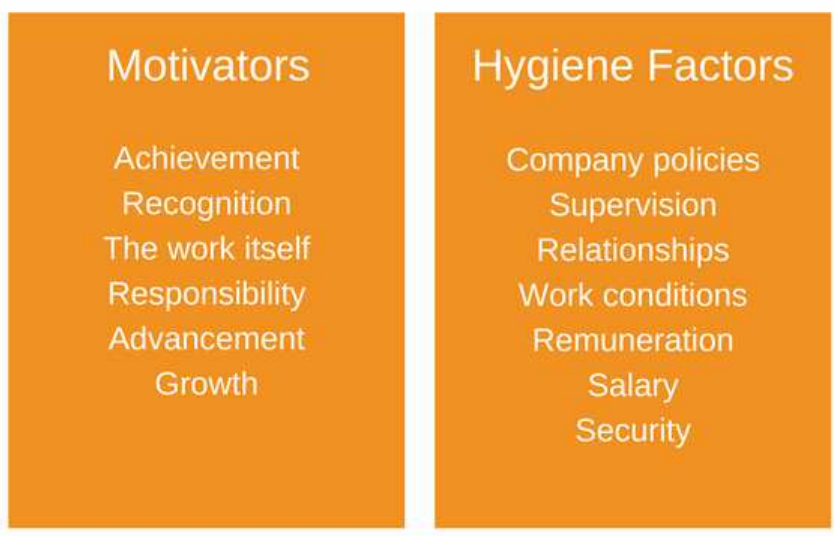

\section{Figure 6 - Herzberg's two-factor theory}

Based on the above incentive theory, this paper analyzes the human resource management of the financial industry and launches the following discussion.

The relationship between enterprises is different from before. To achieve long-term development, enterprises must cooperate with employees to achieve mutual benefit and win-win results. Based on this, financial institutions should strictly follow the following three points when formulating employee incentive management measures.

If financial institutions want to give full play to the advantages of Internet finance, they must strengthen effective communication with employees, give full play to the team's strength, and help financial institutions achieve their own development goals. The traditional business model can no longer meet the development needs of the current Internet era. Therefore, financial institutions should build the corresponding information network platform according to their conditions, strengthen the attention to employees, and improve the overall management efficiency.

Financial institutions should seize the development characteristics of Internet finance, improve the human resource management model, constantly innovate the business model, and optimize the human resource efficiency management indicators.

In the Internet financial mode, the work can be done through many fragments of time, this is a traditional financial institution cannot be achieved, so the current financial institutions should change the inherent ideas, guide staff to decompose, daily work inspire employees more value, improve the work efficiency, thus alleviate financial institutions operating costs, improve overall value.

Staff incentive problems existing in modern enterprise management and corresponding solutions. With the development of the market economy, having an effective incentive mechanism has been regarded as the driving force for the sustainable development of enterprises and a magic weapon to win the competition. Because the only incentive can make employees try their best to work for it, reduce the cost of the enterprise. However, as an activity to stimulate people's psychological motivation, motivation is the most complex and challenging task in management.

Although salary can play an incentive role in some cases, it is only a short-term incentive. Moreover, when people's material needs are met, the incentive effect of pay will be ineffective because the person's demand comes from distinguishing between material demand and spiritual demand. These needs are the basis of human motivation and behavior; when people lack a specific need, it will prompt people to have the motivation to obtain this need, and under the promotion of this motivation, stimulate people to make the corresponding behavior.

Although innovative incentive methods play an essential role, enterprises should pay attention to the formulation of incentive methods: first of all, enterprises should start from their actual situation, according to the employees' ideals, interests and needs level to formulate. For the employees who take life demand as their advantage, the incentive should be more important than meeting their daily necessities, food, clothing, housing and transportation. For employees who are more concerned with self-actualization, generous material rewards are less likely to stimulate their work enthusiasm than a challenging job. Furthermore, for the staff with higher artistic quality, the spiritual need is often more urgent than money.

Existing problems in employee incentive in financial institutions:

1. There are only short-term incentives, ignoring long-term incentives.

Modern enterprises in the use of incentives often only focus on immediate interests, meet the most basic immediate needs, and take some short-term incentive methods, such as pay increases, bonuses, etc. More some enterprises use depreciation, tax evasion and other illegal means to increase book profits. Although these incentive methods can enable enterprises to achieve short-term goals, they generally cannot play a lasting incentive role, and it is easy to cause motivated people to give up long-term interests due to excessive concern for the short-term interests of the enterprise. This is not conducive to the sustainable development of the enterprise, nor can it retain talents for the enterprise. If an enterprise wants to establish a "long-term contractual relationship" with people, it needs to use long-term incentive methods.

2. The assessment system and reward system are not perfect. 
Sound performance evaluation mechanism and fair reward system are important components of enterprise incentive mechanism. Performance evaluation refers to assessing and evaluating the actual effect of employee behavior and its contribution and value to the enterprise by applying various scientific qualitative and quantitative methods to the work undertaken by each employee in the enterprise.

3. Insufficient incentives for business operators

Nowadays, many enterprises hold the one-sided view that as long as they focus on employees' incentive, they ignore the incentive of business operators. In fact, as an enterprise operator, he is not only an essential part of an enterprise but also his personality and behavior have a significant impact on employees. If the operator can be everywhere to set an example, consistent with words and deeds, honest and diligent, will influence the employees through the example role and stimulate their enthusiasm for work.

Conclusion. In fact, no matter what kind of enterprise, development is inseparable from the creativity and enthusiasm of people. That is to say, any enterprise needs incentives, and only under the appropriate incentive mechanism can enterprises achieve the practical state of "people make full use of their resources". However, as discussed in the above article, there are inevitably some problems motivating employees, and every enterprise should pay attention to these problems. Because of the above analysis, employee motivation is simply a process of mobilizing internal causes by adjusting external causes to motivate the motivated to develop in the direction expected by the motivator. That looking for the employee incentive problem in modern enterprise management from the reality and making the corresponding solutions.

\section{References.}

1. Xie, Lei (2020). Optimization of human resource performance management in big data enterprises based on SWOT analysis. Statistics and management. 35 (07). PP. 69-73

2. Chen, Wenlan (2019). Research and analysis of human capital from the perspective of strategic human resource management. Guangxi quality supervision guide. (08). PP. 11-12.

3. Cui, Maojun (2015). One belt, one road, Guangxi's development, strengths and weaknesses, and development path. Journal of Nanning College for Vocational Technology. 20 (06). PP. 97-100.

4. Wang, Yuxue (2012). Rural human resource development and rural regional economic development. Chongqing Normal University.

5. Hasan, I., Wachtel, P. and Zhou, M. (2009). Institutional Development, Financial Deepening and Economic Growth: Evidence from China. Journal of Banking and Finance. Vol.33. No.1. PP.157-170. 